\title{
International Journal of ASIAN STUDIES
}

\section{Instructions for contributors}

IJAS publishes research on Asia, primarily in the social sciences and humanities. The Journal is particularly interested in locating contemporary changes within a historical framework, especially using interdisciplinary approaches, and promotes comparative studies involving the various regions of Asia. While the Journal will publish scholars from around the world, it aims to focus attention on the work of Asian scholars, in order to encourage multi-directional scholarly communication in Asian studies. IJAS seeks both original papers and survey articles that fall within its scope. Since the Journal is attempting to cross methodological boundaries, it will welcome papers that develop new methodologies within their general approach. For further information, visit www.ioc.u-tokyo.ac.jp/pub/i-journal_as/journal.htm

\section{Submissions}

Articles submitted for publication should be sent by email to the Managing Editors at ej@ioc.u-tokyo.ac.jp.

Postal correspondence may be sent to The Managing Editors, International Journal of Asian Studies, Institute for Advanced Studies on Asia, University of Tokyo, 7-3-I Hongo, Bunkyo-ku, Tokyo I I3-0033, Japan.

Submission of a paper will be taken to imply that it is unpublished and is not being considered for publication elsewhere. Upon acceptance of a paper, the authors will be asked to assign copyright to Cambridge University Press.

Contributors are responsible for obtaining permission to reproduce any materials, including photographs and illustrations, for which they do not hold copyright and for ensuring that the appropriate acknowledgements are included in the manuscript.

All contributions in the journal are peer-reviewed.

\section{Manuscript preparation}

Papers must be in English and in principle no more than I 2,00o words in length, including footnotes, normally to be submitted by email attachment as a Word file. The title of the manuscript, author's name, institutional affiliation, address, email address, and an abstract of up to 200 words should appear at the top of the file. Submissions, or enquiries about prospective submissions, may be sent to the Editors via ej@ioc.u-tokyo.ac.jp.

\section{Text conventions}

It is essential that contributors observe the journal's text conventions closely. Contributors should refer to the Journal's rules of citation and points of style, which can be found at http://assets.cambridge.org/LJIL/asi_ifc.pdf. In order to facilitate comprehension among the broadest possible readership, contributors will normally be expected to provide Chinese or Japanese fonts for terms, bibliographical references, names of places and personages, etc where applicable.

\section{Proofs}

Only essential typographical or factual errors may be changed at proof stage. Resist the temptation to revise or add to the text. The publisher reserves the right to charge authors for correction of non-typographical errors.

\section{Offprints}

A pdf offprint will be supplied to the contributor at no charge. Production of traditional offprints can be ordered for a small fee. 


\section{international journal of ASIAN STUDIES}

volume $8 \cdot$ part $1 \cdot$ january 2011

1 Chinese Lacquerwares from Begram: Date and Provenance Liangren Zhang

25 Attorney on Trial: When Lawyers Met Phony Lawyers in Republican Beijing Michael Hoi-Kit Ng

41 Backlash, Fight Back, and Back-Pedaling: Responses to State Feminism in Contemporary Japan

Ayako Kano

\section{Review articles}

63 One Giant Leap in the Study of the Chinese Crescent: A Superb Annotated Translation of Liu Zhi's Nature and Principle in Islam Tatsuya Nakanishi

73 The Wanli Emperor and Ming China's Defence of Korea against Japan James B. Lewis

81 Two Recent Contributions and New Horizons in Modern Tibetan History Nicole Willock

89 The Consciousness of the Past in the Creativity of the Present: Modern Tibetan Literature and Social Change Lama Jabb

\section{Book reviews}

